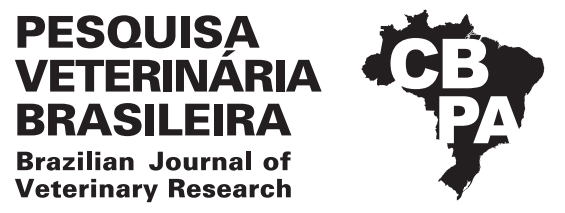

Pesq. Vet. Bras. 39(5):342-347, May 2019 DOI: $10.1590 / 1678-5150-P V B-5819$

ISSN 0100-736X (Print)

ISSN 1678-5150 (Online)

\title{
Serum proteinogram and biochemistry of Holstein cows in the peripartum period ${ }^{1}$
}

\author{
Thaís G. Rocha ${ }^{2 *}$ (D), Camila Bortoletto², Daniela G. Silva², Kalina M.M.G. Simplício², \\ Luiz F. Zafalon ${ }^{3}$ and José J. Fagliari ${ }^{2}$
}

\begin{abstract}
Rocha T.G., Bortoletto C., Silva D.G., Simplício K.M.M.G., Zafalon L.F. \& Fagliari J.J. 2019. Serum proteinogram and biochemistry of Holstein cows in the peripartum period. Pesquisa Veterinária Brasileira 39(5):342-347. Faculdade de Ciências Agrárias e Veterinárias, Universidade Estadual Paulista "Julio de Mesquita Filho", Via de Acesso Prof. Paulo Donato Castellane s/n, Jaboticabal, SP 14884-900, Brazil. E-mail: thaisgrocha@yahoo.com.br

In face of the few reports found in national literature analyzing the potential influence of parturition number in serum proteinogram and biochemical profile in the peripartum period of high yielding dairy cows, the aim of the present study was to comparatively evaluate the dynamics of these serum constituents' concentrations in blood samples obtained from primiparous and multiparous Holstein cows, 60 and 30 days prepartum and in the day of parturition. Data were analyzed by repeated measures variance analysis (ANOVA) and differences between groups and moments were analyzed by Tukey's test. Results were considered significant when $\mathrm{P}<0.05$. Parity influenced levels of total protein, albumin, globulins, magnesium, cholesterol, which were higher in multiparous cows, as well as concentrations of ceruloplasmin, total calcium, chloride and alkaline phosphatase activity, which were higher in primiparous cows. Parturition influenced serum concentrations of ceruloplasmin $(+58 \%)$, transferrin $(-25 \%)$, haptoglobin $(+33 \%)$, total protein $(-17 \%)$, globulins $(-25 \%)$, immunoglobulin A (-43\%), immunoglobulin G $(-24 \%)$, total calcium $(-12 \%)$, inorganic phosphorus $(-10 \%)$, chloride $(+5 \%)$, sodium $(+4 \%)$, cholesterol $(-23 \%)$, triglycerides $(-38.6 \%)$, as well as activities of aspartate aminotransferase $(+14 \%)$ and alkaline phosphatase $(+28 \%)$. A decrease in serum levels of total calcium, inorganic phosphorus, cholesterol and triglycerides was more pronounced in multiparous than in primiparous cows. These results demonstrate that the interpretation of proteinogram and serum constituents should take into consideration lactation number and the moment of parturition as relevant factors in high yielding dairy cows in the transition period.
\end{abstract}

INDEX TERMS: Proteinogram, biochemistry, Holstein cows, peripartum period, transition period, multiparous, primiparous, acute phase proteins, cattle, morphology.

\begin{abstract}
RESUMO.- [Proteinograma e bioquímica séricas de vacas da raça Holandesa no período periparto.] Diante da escassez de relatos encontrados na literatura nacional quanto à potencial influência do número de parições sobre o proteinograma sérico e perfil bioquímico no período periparto de vacas leiteiras de alta produção, o objetivo do
\end{abstract}

\footnotetext{
${ }^{1}$ Received on November 6, 2018.

Accepted for publication on November 21, 2018.

${ }^{2}$ Faculdade de Ciências Agrárias e Veterinárias, Universidade Estadual Paulista "Julio de Mesquita Filho" (Unesp), Via de Acesso Prof. Paulo Donato Castellane s/n, Jaboticabal, SP 14884-900, Brazil. *Corresponding author: thaisgrocha@yahoo.com.br

${ }^{3}$ Embrapa Pecuária Sudeste, Rod. Washington Luiz Km 234 s/n, Fazenda Canchim, São Carlos, SP 13560-970, Brazil.
}

presente estudo foi avaliar comparativamente a dinâmica de constituintes séricos em amostras de sangue obtidas de vacas da raça Holandesa primíparas e pluríparas, 60 e 30 dias pré-parto e no dia do parto. Os resultados foram avaliados por análise de variância (ANOVA) com medidas repetidas no tempo e as diferenças entre grupos e entre momentos foram analisadas pelo teste de Tukey, sendo os resultados considerados significativos quando $\mathrm{P}<0,05$. 0 número de parições influenciou os teores de proteína total, albumina, globulinas, magnésio e colesterol, que foram maiores em vacas pluríparas, bem como as concentrações de ceruloplasmina, cálcio total, cloreto e atividade de fosfatase alcalina, que foram maiores em vacas primíparas. 0 número de parições influenciou as concentrações séricas de ceruloplasmina 
(+58\%), transferrina (-25\%), haptoglobina (+33\%), proteína total $(-17 \%)$, globulinas $(-25 \%)$, imunoglobulina A $(-43 \%)$, imunoglobulina G $(-24 \%)$, cálcio total $(-12 \%)$, fósforo $(-10 \%)$, cloretos (+5\%), sódio (+4\%), colesterol (-23\%), triglicérides $(-38.6 \%)$, bem como as atividades de aspartato aminotransferase $(+14 \%)$ e fosfatase alcalina (+28\%). A diminuição do teor sérico de cálcio total, fósforo, colesterol e triglicérides foi mais acentuada em vacas pluríparas do que em vacas primíparas. Esses resultados mostram que a interpretação do proteinograma e dos constituintes séricos deve levar em consideração o número de lactações e a ocorrência do parto como fatores relevantes em vacas leiteiras de alta produção no período de transição.

TERMOS DE INDEXAÇÃO: Proteinograma, bioquímica, vacas Holandesas, período periparto, período de transição, pluríparas, primíparas, proteínas de fase aguda, bovinos, morfologia.

\section{INTRODUCTION}

Laboratorial analysis is an important tool that collaborates with health status evaluation of cows, individually and as part of the herd (Cozzi et al. 2011). The determination of metabolic profile of dairy cows is also relevant for early diagnosis, treatment and prevention of production diseases in the peripartum period, as the negative consequences of health problems in the time around calving are well known and might influence production, especially in early lactation (Van Saun 2007, Silva 2009). Besides, data regarding biochemical analysis of cows in the peripartum period are usually compared to reference values, which are normally obtained from animals in mid to late lactation, which means they may not be appropriate for comparison with transition cows (Van Saun 2004).

The aim of this study was to evaluate the influence of parity on the proteinogram, and serum biochemistry profile of high yielding Holstein cows, 60 and 30 days prepartum and in the day of parturition.

\section{MATERIALS AND METHODS}

The experimental design was approved by the Animal Ethics Committee of the School of Veterinary Medicine of the São Paulo State University (Unesp), Jaboticabal Campus, under protocol number 015110/10. Forty-eight clinically healthy pregnant Holstein cows were allotted in two experimental groups comprising 24 animals each: group $\mathrm{P}$ (primiparous cows) and group M (multiparous cows). Cows from both groups belonged to the same herd, where mean milk yield was 32 liters/cow/day, and the experimental period extended from January 2010 to April 2011.

The diet of cows is shown in Tables 1 and 2, and consisted of two different formulations, according to the period before parturition. Between -60 days and -30 days prepartum the cows received the prepartum diet, and from -30 days pre-partum until parturition the anionic diet was provided to the animals. Animals belonging to groups $\mathrm{P}$ and $\mathrm{M}$ were allotted in different pens.

Cows from both groups were vaccinated 60 and 30 days prepartum with (1) a commercial vaccine containing strains G6P[1] and G10P[11] of inactivated rotavirus, dead coronavirus, Escherichia coli K99 colibacterin and type C Clostridium perfringens toxoid according to manufacturer's recommendations - pregnant cows and heifers received two doses, intramuscularly, with approximately 3 weeks interval between doses, and the second dose between 3 and 6 weeks prepartum; (2) vaccine containing Salmonella Dublin suspension, Pasteurella multocida, and Salmonella Typhimurium in saline solution, phenicated at $0.5 \%$ inactivated by the addition of $40 \%$ formalin; (3) commercial vaccine containing a lyophilized preparation of chemically altered live samples of infectious bovine rhinotracheitis virus (IBR), and parainfluenza 3 virus (PI3) associated with a live modified bovine respiratory syncytial virus (BRSV) strain, a diluent that consisted in an inactivated combination of cytopathic and non-cytopathic BVD virus and inactivated cultures of five serotypes of Leptospira spp.

Blood samples were taken from the cows by jugular venipuncture; using Vacutainer ${ }^{\circledR}$ tubes (Vacutainer, Becton Dickinson, Franklin Lakes/NJ, USA) without anticoagulant, in three occasions: 60 days (M-60), and 30 days (M-30) prepartum and immediately after parturition (M0). Blood samples were centrifuged at 1,000 x g for 10 minutes, and serum was stored at $-20^{\circ} \mathrm{C}$ until analysis.

Electrophoretic separation of serum proteins was carried out in polyacrylamide gels (SDS-PAGE) using the technique described by Laemmli (1970). After separation of protein fractions, the gel was colored in a $0.2 \%$ coomassie blue solution. Protein concentrations were determined by use of computer-assisted densitometry (Shimadzu CS-9301PC, Tokyo, Japan). Reference markers (Sigma, St Louis/MO, USA) with molecular weights of $24 \mathrm{kDa}, 29 \mathrm{kDa}, 36 \mathrm{kDa}, 45 \mathrm{kDa}$, $55 \mathrm{kDa}, 66 \mathrm{kDa}, 97 \mathrm{kDa}, 116 \mathrm{kDa}$, and $205 \mathrm{kDa}$ were used to identify

Table 1. Formulation of concentrates received by the cows throughout the experimental period

\begin{tabular}{|c|c|}
\hline $\begin{array}{l}\text { Prepartum concentrate } \\
(-60 \text { and }-30 \text { prepartum) }\end{array}$ & $\begin{array}{l}\text { Anionic concentrate } \\
\text { (-30 and } 0 \text { prepartum) }\end{array}$ \\
\hline Vitamin E & Coline \\
\hline Corn grain & Vitamin E \\
\hline 570 ca nutron & SALUS NA ${ }^{\circledR e}$ \\
\hline Urea & Corn grain \\
\hline Yeast & Vitamin AD3 \\
\hline \multirow[t]{2}{*}{ Magnesium oxide } & Yeast \\
\hline & Urea \\
\hline Mycofix $^{\circledR a}$ & Mycofix $^{\circledR a}$ \\
\hline SELPLEX $^{\circledR b}$ & SELPLEX $^{\circledR b}$ \\
\hline Probios $^{\circledR c}$ & Biotin \\
\hline Difly ${ }^{\circledR d}$ & Difly $^{\circledR d}$ \\
\hline Biotin & Probios $^{\circledR C}$ \\
\hline
\end{tabular}

a Biomin do Brasil LTDA, Piracicaba/SP, Brazil; ' ${ }^{\text {b }}$ S-Vet Nutrição Animal, Pato Branco/PR, Brazil; ' Ourofino Saúde Animal, Cravinhos/SP, Brazil; d Champion Farmoquímico LTDA, Anápolis/GO, Brazil; ' Salus Group, Santo Antônio da Posse/SP, Brazil.

Table 2. Diet composition received by the cows throughout the experimental period

\begin{tabular}{lrlc}
\hline $\begin{array}{c}\text { Prepartum diet } \\
\text { (-60 and -30 prepartum) }\end{array}$ & $\mathrm{kg} / \mathrm{cow}$ & $\begin{array}{c}\text { Anionic diet } \\
(-30 \text { and 0 prepartum })\end{array}$ & $\mathrm{kg} / \mathrm{cow}$ \\
\hline $\begin{array}{l}\text { Prepartum concentrate } \\
\text { (Table 1) }\end{array}$ & 0.8 & $\begin{array}{l}\text { Anionic concentrate } \\
\text { (Table } 1)\end{array}$ & 1.0 \\
Soybean & 1.2 & Soybean & 1.9 \\
Wheat hay & 1.88 & Sugar cane bagasse & 2.5 \\
Sugar cane bagasse & 1.33 & Wheat hay & 2.0 \\
Tifton grass & 14.81 & Silage & 14.33 \\
Corn Silage & 9.56 & &
\end{tabular}


protein fractions associated with the electrophoretic mobility of purified immunoglobulin A, immunoglobulin G, ceruloplasmin, transferrin, and haptoglobin (Sigma, St Louis/MO, USA).

Concentrations of total protein, albumin, urea, activities of gamma-glutamyl transferase (GGT), alkaline phosphatase (ALP), and aspartate aminotransferase (AST), as well as levels of total calcium, phosphorus, magnesium, chloride, cholesterol, and triglycerides were determined spectrophotometrically, using commercial reagents (Labtest Diagnóstica, Lagoa Santa, Minas Gerais, Brazil). Concentrations of ionized calcium, sodium, and potassium were determined by the selective ion method using an automatic electrolyte analyzer (9180 Electrolyte Analyzer, Roche Diagnostics, Mannheim, Germany). Globulin level was determined arithmetically based on the difference between total protein and albumin concentrations in serum.

Data obtained were analyzed by repeated measures ANOVA and the differences between groups and moments were compared by Tukey test, considered significant at $\mathrm{P}<0.05$.

\section{RESULTS AND DISCUSSION}

In the moment of parturition (M0), there was a significant change in levels of acute phase proteins ceruloplasmin and haptoglobin, which increased $61.9 \%$ in group $\mathrm{P}$ and $54.3 \%$ in group $\mathrm{M}$, and $24 \%$ in group $\mathrm{P}$, and $33.7 \%$ in group $\mathrm{M}$, respectively (Table 3 ). Silva (2009) and Bossaert et al. (2012) reported an increase in ceruloplasmin levels due to parturition in comparison to prepartum sampling moments, which is in agreement with the findings of the present study. The transition period is a time of immunosuppression, characterized by a marked decrease in the ability to respond to injuries and infectious challenge and so, as ceruloplasmin and haptoglobin are positive acute phase proteins in cows, this increase is expected due to the intensity of physiological and pathological events that precede parturition (Eckersall 2008). However, it is interesting to point out that although haptoglobin is considered a major acute phase protein in cows, the most significant increase observed in the acute phase protein profile evaluated by SDS-PAGE was in the concentrations of ceruloplasmin. Ceruloplasmin levels were higher in group $\mathrm{P}$ when compared to group $\mathrm{M}$ in M-30 and M0, which might be due to a stronger response of primiparous cows to the inflammatory stress caused by parturition. There was no significant difference between groups regarding haptoglobin levels, which agree with the report of Schneider et al. (2013).

Transferrin levels decreased $22.6 \%$ in group $P$ and $28.4 \%$ in group $\mathrm{M}$ in $\mathrm{M} 0$ when compared to M-60, and did not differ between groups (Table 3). This result was expected since transferrin is a negative acute phase protein in cows, so its concentration decreases in the face of inflammatory events such as parturition or other common events in the peripartum period, as metritis, mastitis, placental retention and ketosis (Kaneko et al. 2008). Due to the limited number of animals in the present study and the low number of cows affected by these conditions ( 2 cows in group M presented placental retention), such events are not discussed in depth in the present study.

For the moments evaluated, $\alpha_{1}$-acid glycoprotein concentrations were not influenced by parturition or number of lactations, and varied between $8.43 \pm 4.67$ and $9.50 \pm 6.94 \mathrm{mg} / \mathrm{dL}$ in group $\mathrm{P}$ and $9.20 \pm 5.67$ and $10.1 \pm 6.93 \mathrm{mg} / \mathrm{dL}$ in group M. As a moderate acute phase protein in cows whose levels increase slower but are maintained for a longer period (Kaneko et al. 2008) the evaluation of $\alpha_{1}$-acid glycoprotein levels would probably be more useful as a marker of puerperal diseases, and for this purpose, samples should have been taken in more occasions after parturition.

Throughout the experimental period, although in M-60 there was no difference between groups, the concentration of total protein (Table 3) was higher in group M when compared to group P, which can be explained by the cumulative effect the continuing exposure of animals to antigens present in the environment has on the globulin fraction of serum proteins, so the concentrations of total proteins tend to increase with age (Larson \& Touchberry 1959). Between moments, the decrease in total protein levels in $\mathrm{M} 0$ in both groups is a result of the transference of globulins from the bloodstream to the mammary gland secretions, a process called colostrogenesis (Birgel Junior et al. 2003). The difference observed between primiparous and multiparous cows regarding serum concentrations of total protein might influence colostrum quality, which is usually higher in multiparous cows (Rocha et al. 2012). Alvarenga et al. (2015) did not report differences in

Table 3. Mean and standard-error of protein and metabolite concentrations of primiparous (Group P) and multiparous (Group M) Holstein cows 60 (M-60), and 30 (M-30) days prepartum and in the day of parturition (M0)

\begin{tabular}{|c|c|c|c|}
\hline \multirow{2}{*}{ Groups } & \multicolumn{3}{|c|}{ Time } \\
\hline & M-60 & M-30 & M0 \\
\hline \multicolumn{4}{|c|}{ Ceruloplasmin (mg/dL) } \\
\hline $\mathrm{P}$ & $50.1 \pm 5.83 \mathrm{Ab}$ & $51.0 \pm 3.05 \mathrm{Ab}$ & $82.6 \pm 6.56 \mathrm{Aa}$ \\
\hline M & $37.1 \pm 3.46 \mathrm{Ab}$ & $34.6 \pm 2.35 \mathrm{Bb}$ & $53.4 \pm 6.58 \mathrm{Ba}$ \\
\hline \multicolumn{4}{|c|}{ Transferrin (mg/dL) } \\
\hline $\mathrm{P}$ & $341 \pm 21.4 \mathrm{Aa}$ & $333 \pm 22.1 \mathrm{Aa}$ & $264 \pm 26.8 \mathrm{Ab}$ \\
\hline M & $317 \pm 22.7 \mathrm{Aa}$ & $303 \pm 20.2 \mathrm{Ab}$ & $227 \pm 23.8 \mathrm{Ab}$ \\
\hline \multicolumn{4}{|c|}{ Haptoglobin (mg/dL) } \\
\hline $\mathrm{P}$ & $18.9 \pm 2.93 \mathrm{Ab}$ & $20.8 \pm 2.88 \mathrm{Aab}$ & $25.8 \pm 3.21 \mathrm{Aa}$ \\
\hline M & $20.6 \pm 1.92 \mathrm{Aab}$ & $18.7 \pm 1.55 \mathrm{Ab}$ & $25.0 \pm 2.44 \mathrm{Aa}$ \\
\hline \multicolumn{4}{|c|}{ Total protein $(\mathrm{g} / \mathrm{dL})$} \\
\hline $\mathrm{P}$ & $7.93 \pm 0.11 \mathrm{Aa}$ & $7.81 \pm 0.10 \mathrm{Ba}$ & $6.48 \pm 0.17 \mathrm{Ab}$ \\
\hline M & $8.21 \pm 0.12 \mathrm{Aa}$ & $8.39 \pm 0.11 \mathrm{Aa}$ & $6.90 \pm 0.13 \mathrm{Ab}$ \\
\hline \multicolumn{4}{|c|}{ Albumin (g/dL) } \\
\hline $\mathrm{P}$ & $2.64 \pm 0.06 \mathrm{Aa}$ & $2.55 \pm 0.04 \mathrm{Aa}$ & $2.54 \pm 0.04 \mathrm{Ba}$ \\
\hline M & $2.62 \pm 0.06 \mathrm{Aab}$ & $2.55 \pm 0.07 \mathrm{Ab}$ & $2.74 \pm 0.06 \mathrm{Aa}$ \\
\hline \multicolumn{4}{|c|}{ Globulins (g/dL) } \\
\hline $\mathrm{P}$ & $5.29 \pm 0.11 \mathrm{Aa}$ & $5.26 \pm 0.11 \mathrm{Ba}$ & $3.94 \pm 0.16 \mathrm{Ab}$ \\
\hline M & $5.58 \pm 0.15$ Аа & $5.83 \pm 0.11 \mathrm{Aa}$ & $4.16 \pm 0.13 \mathrm{Ab}$ \\
\hline \multicolumn{4}{|c|}{ Immunoglobulin A (mg/dL) } \\
\hline $\mathrm{P}$ & $79.7 \pm 6.67 \mathrm{Aа}$ & $89.2 \pm 7.36 \mathrm{Aa}$ & $50.0 \pm 5.05 \mathrm{Ab}$ \\
\hline M & $90.9 \pm 7.56 \mathrm{Aa}$ & $93.6 \pm 7.45 \mathrm{Aa}$ & $46.4 \pm 7.56 \mathrm{Ab}$ \\
\hline \multicolumn{4}{|c|}{ Immunoglobulin G (mg/dL) } \\
\hline $\mathrm{P}$ & $2,098 \pm 71.2 \mathrm{Aa}$ & $2,242 \pm 72.4 \mathrm{Aa}$ & $1,715 \pm 87.0 \mathrm{Ab}$ \\
\hline $\mathrm{M}$ & $2,314 \pm 94.0 \mathrm{Aa}$ & $2,312 \pm 71.8 \mathrm{Aa}$ & $1,731 \pm 138 \mathrm{Ab}$ \\
\hline \multicolumn{4}{|l|}{ Urea (mg/dL) } \\
\hline $\mathrm{P}$ & $17.5 \pm 1.45 \mathrm{Aa}$ & $20.0 \pm 1.22 \mathrm{Aa}$ & $19.8 \pm 1.52 \mathrm{Aa}$ \\
\hline M & $22.0 \pm 1.66 \mathrm{Aa}$ & $20.7 \pm 1.48 \mathrm{Aa}$ & $24.8 \pm 2.05 \mathrm{Aa}$ \\
\hline
\end{tabular}

Mean values followed by the same upper case letters in the same column and lower case letters on the same line do not differ significantly according to Tukey test $(\mathrm{P}<0.05)$. 
total protein concentrations in Holstein cows in the transition period, which disagrees with the findings of the present study.

In group $\mathrm{M}$, concentration of albumin in M-30 was significantly lower when compared to M0 (Table 3). According to Birgel Junior et al. (2003), non-gestating heifers and animals at first and second thirds of gestation present higher levels of albumin than animals in the last third of pregnancy and the early postpartum. Bossaert et al. (2012) reported a decrease of albumin levels around calving, which was not noticed in the present experiment.

In $\mathrm{M}-30$, the serum levels of globulins were higher in group $\mathrm{M}$, when compared to group $\mathrm{P}$ which might also be due to the continuing exposure and increased ability of older cows to respond to antigens when compared to heifers, since vaccination schemes did not differ between groups. Between moments, a decrease in this protein fraction concentration in M0 when compared to M-30 was similar to the dynamics observed in serum levels of IgA (decrease of $43.9 \%$ in group P and $50.4 \%$ in group M) and IgG (decrease of $23.5 \%$ in group $P$ and $25.1 \%$ in group M) (Table 3 ). This tendency corroborates the data reported previously by other authors, who state that the transference of immunoglobulins to the mammary gland secretions during colostrogenesis causes a typical decrease of globulin concentrations in blood serum and might influence the ability of cows to respond immunologically to challenges presented in the transition period (Birgel Junior et al. 2003, Silva 2009).

Urea concentrations were higher in group $M$ when compared to group P in M-60 and M0, although in both groups, no difference was noticed between moments (Table 3). It is important to evaluate urea concentrations as a way to verify that dietary protein levels and nitrogen utilization efficiency are adequate (Lager \& Jordan 2012). As multiparous cows receive a better diet in order to support higher milk yield, it is expected that these animals present higher levels of urea in blood serum when compared to primiparous cows.

Serum activity of GGT (Table 4) was higher in group $\mathrm{M}$, when compared to group P at M-60. Birgel Junior et al. (2003) found no influence of gestational period or puerperium on the activity of this enzyme, contrary to the reported by Cozzi et al.

Table 4. Mean and standard-error of serum activities of enzymes of primiparous (Group P) and multiparous (Group M) Holstein cows 60 (M-60), and 30 (M-30) days prepartum and in the day of parturition (M0)

\begin{tabular}{cccc}
\hline \multirow{2}{*}{ Groups } & \multicolumn{3}{c}{ Time } \\
\cline { 2 - 4 } M- 60 & M-30 & M0 \\
\hline \multicolumn{4}{c}{ Gamma glutamyl-transferase (U/L) } \\
P & $24.4 \pm 1.43 \mathrm{Aab}$ & $23.0 \pm 1.60 \mathrm{Ab}$ & $26.2 \pm 2.16 \mathrm{Aa}$ \\
M & $38.9 \pm 9.46 \mathrm{Aa}$ & $34.1 \pm 4.08 \mathrm{Aa}$ & $31.9 \pm 1.77 \mathrm{Aa}$ \\
Alkaline phosphatase (U/L) & & \\
P & $67.6 \pm 4.91 \mathrm{Ab}$ & $67.5 \pm 6.14 \mathrm{Ab}$ & $88.4 \pm 8.96 \mathrm{Aa}$ \\
M & $44.6 \pm 4.784 \mathrm{Bb}$ & $49.0 \pm 4.63 \mathrm{Ab}$ & $61.5 \pm 5.98 \mathrm{Ba}$ \\
Aspartate aminotransferase (U/L) & & \\
P & $53.7 \pm 1.77 \mathrm{Ab}$ & $53.6 \pm 1.41 \mathrm{Ab}$ & $59.9 \pm 1.57 \mathrm{Aa}$ \\
M & $54.6 \pm 2.98 \mathrm{Ab}$ & $54.6 \pm 3.01 \mathrm{Ab}$ & $63.5 \pm 3.79 \mathrm{Aa}$
\end{tabular}

Mean values followed by the same upper case letters in the same column and lower case letters on the same line do not differ significantly according to Tukey test $(\mathrm{P}<0.05)$.
(2011). The difference found in the present study might be attributable to the higher incidence of hepatic disorders in older cows when compared to heifers, although the values reported here are only slightly higher than the reference values for cows found in literature (Kaneko et al. 2008) and individual evaluations did not show laboratorial evidence of hepatic disease in the animals studied (data not shown).

Serum activity of AST increased in both groups in M0 (Table 4) probably due to the intense muscular activity involved in the parturition process (Birgel Junior et al. 2003) and also due to the higher probability of liver damage as a result of negative energy balance resulting in hepatic lipidosis, especially in multiparous cows.

ALP activity was higher in group $P$ when compared to group $\mathrm{M}$ in all the moments evaluated (Table 4), probably due to the higher osteoblastic activity of heifers, as reported by Cozzi et al. (2011), who found activities of ALP of $116 \mathrm{U} / \mathrm{L}$ in primiparous cows and of $90 \mathrm{U} / \mathrm{L}$ in multiparous cows. An increase in ALP activity was also found in M0, when compared to M-60 and M-30 in both groups, which is probably due to placental ALP released in the bloodstream by the time of parturition.

Serum concentration of total calcium was significantly lower in group $\mathrm{M}$ at M0, when compared to group $\mathrm{P}$ (Table 5). Although hypocalcemia may affect cows at any age, it is most common in multiparous dairy cows entering their third or greater lactation, which explains why calcium levels were lower in multiparous than in primiparous cows (Barrington 2013). Both groups presented lower total calcium concentrations at M0 when compared to M-60 and M-30. Contrary to these findings, Silva (2009) reported lower calcium levels in primiparous cows at parturition, when compared to two or more gestation cows. According to Kaneko et al. (2008), the reference range of total calcium is from 9.70 to $12.4 \mathrm{mg} / \mathrm{dL}$ in cows, which puts the present results below reference range for this parameter in all moments evaluated and in both groups. The evaluation of calcium levels around calving is an indicator of potential development of clinical or subclinical hypocalcemia (Van Saun 2007). One cow in group M presented an episode of puerperal hypocalcemia immediately after parturition, and responded well to treatment with intravenous calcium solution, although the same animal presented placental retention afterwards.

Ionized calcium levels (Table 5) did not differ between groups or moments, and varied from $0.69 \pm 0.25$ to $0.71 \pm 0.28 \mathrm{mMol} / \mathrm{L}$ in group $\mathrm{P}$ and from $0.64 \pm 0.23$ to $0.69 \pm 0.22 \mathrm{mMol} / \mathrm{L}$ in group M. Normal values for cows vary from 1.2 to $1.6 \mathrm{mMol} / \mathrm{L}$ (Kaneko et al. 2008), which indicates that in the present study, as for total calcium, levels of ionized calcium were below reference range for this species, which shows that in the period evaluated, there was an increased risk for the development of puerperal hypocalcemia and associated diseases.

There was no difference between groups regarding inorganic phosphorus concentrations (Table 5). Between moments, both groups presented lower levels of this element at M0, although values found in both groups at all moments evaluated were still within the reference range according to Kaneko et al. (2008), who reported that normal values of inorganic phosphorus concentration in cows range from 5.60 to $6.50 \mathrm{mg} / \mathrm{dL}$. The correspondence between total calcium and inorganic phosphorus concentrations dynamics relies on a balanced mechanism which controls the homeostasis of both elements (Kaneko et al. 2008). 
Table 5. Mean and standard-error of serum concentrations of minerals and lipids of primiparous (Group $P$ ) and multiparous (Group M) Holstein cows 60 (M-60), and 30 (M-30) days prepartum and in the day of parturition (M0)

\begin{tabular}{|c|c|c|c|}
\hline \multirow{2}{*}{ Grupos } & \multicolumn{3}{|c|}{ Time } \\
\hline & M-60 & $\mathrm{M}-30$ & M0 \\
\hline \multicolumn{4}{|c|}{ Total calcium (mg/dL) } \\
\hline $\mathrm{P}$ & $8.88 \pm 0.14 \mathrm{Aa}$ & $8.67 \pm 0.15 \mathrm{Aa}$ & $8.24 \pm 0.13 \mathrm{Ab}$ \\
\hline M & $8.82 \pm 0.14 \mathrm{Aa}$ & $8.64 \pm 0.14 \mathrm{Aa}$ & $7.60 \pm 0.21 \mathrm{Bb}$ \\
\hline \multicolumn{4}{|c|}{ Ionized calcium (mMol/L) } \\
\hline $\mathrm{P}$ & $0.69 \pm 0.05 \mathrm{Aa}$ & $0.70 \pm 0.06 \mathrm{Aa}$ & $0.71 \pm 0.06 \mathrm{Aa}$ \\
\hline M & $0.69 \pm 0.04 \mathrm{Aa}$ & $0.64 \pm 0.05 \mathrm{Aa}$ & $0.68 \pm 0.05 \mathrm{Aa}$ \\
\hline \multicolumn{4}{|c|}{ Phosphorus (mg/dL) } \\
\hline $\mathrm{P}$ & $6.17 \pm 0.14 \mathrm{Aab}$ & $6.25 \pm 0.15 \mathrm{Aa}$ & $5.56 \pm 0.22 \mathrm{Ab}$ \\
\hline M & $6.14 \pm 0.20 \mathrm{Aa}$ & $6.07 \pm 0.13 \mathrm{Aab}$ & $5.47 \pm 0.31 \mathrm{Ab}$ \\
\hline \multicolumn{4}{|c|}{ Magnesium (mg/dL) } \\
\hline $\mathrm{P}$ & $2.17 \pm 0.06 \mathrm{Aa}$ & $2.17 \pm 0.05 \mathrm{Aa}$ & $2.07 \pm 0.06 \mathrm{Ba}$ \\
\hline M & $2.09 \pm 0.05 \mathrm{Ab}$ & $2.09 \pm 0.05 \mathrm{Ab}$ & $2.30 \pm 0.08 \mathrm{Aa}$ \\
\hline \multicolumn{4}{|c|}{ Chloride (mMol/L) } \\
\hline $\mathrm{P}$ & $99.8 \pm 1.28$ Aab & $98.6 \pm 1.37 \mathrm{Ab}$ & $102 \pm 1.50 \mathrm{Aa}$ \\
\hline $\mathrm{M}$ & $94.9 \pm 1.33 \mathrm{Bb}$ & $95.4 \pm 1.59 \mathrm{Ab}$ & $102 \pm 1.33 \mathrm{Aa}$ \\
\hline \multicolumn{4}{|c|}{ Sodium (mMol/L) } \\
\hline $\mathrm{P}$ & $144 \pm 0.94 \mathrm{Ab}$ & $143 \pm 0.91 \mathrm{Ab}$ & $147 \pm 1.12 \mathrm{Aa}$ \\
\hline M & $141 \pm 0.67 \mathrm{Ab}$ & $144 \pm 1.08 \mathrm{Ab}$ & $150 \pm 1.03 \mathrm{Aa}$ \\
\hline \multicolumn{4}{|c|}{ Potassium (mMol/L) } \\
\hline $\mathrm{P}$ & $4.38 \pm 0.07 \mathrm{Ab}$ & $4.65 \pm 0.08 \mathrm{Aa}$ & $4.55 \pm 0.06 \mathrm{Aab}$ \\
\hline $\mathrm{M}$ & $4.45 \pm 0.05 \mathrm{Aa}$ & $4.53 \pm 0.06 \mathrm{Aa}$ & $4.51 \pm 0.06 \mathrm{Aa}$ \\
\hline \multicolumn{4}{|c|}{ Cholesterol (mg/dL) } \\
\hline $\mathrm{P}$ & $70.1 \pm 2.35 \mathrm{Ba}$ & $67.4 \pm 2.03 \mathrm{Aa}$ & $57.2 \pm 2.13 \mathrm{Ab}$ \\
\hline M & $89.4 \pm 5.72 \mathrm{Aa}$ & $75.8 \pm 3.34 \mathrm{Ab}$ & $58.3 \pm 2.17 \mathrm{Ac}$ \\
\hline \multicolumn{4}{|c|}{ Triglycerides (mg/dL) } \\
\hline $\mathrm{P}$ & $20.6 \pm 1.05 \mathrm{Aa}$ & $21.6 \pm 1.08 \mathrm{Aa}$ & $14.3 \pm 1.19 \mathrm{Ab}$ \\
\hline M & $21.5 \pm 1.58 \mathrm{Aa}$ & $21.2 \pm 1.20 \mathrm{Aa}$ & $13.0 \pm 0.84 \mathrm{Ab}$ \\
\hline
\end{tabular}

Mean values followed by the same upper case letters in the same column and lower case letters on the same line do not differ significantly according to Tukey test $(\mathrm{P}<0.05)$.

Magnesium levels were lower in group P when compared to group M at M0 (Table 5). Between moments, an increase of this elements concentration was found in group M at M0 when compared to the remaining moments evaluated. Despite of these findings, magnesium concentration remained in the normal range for cows, which varies from 1.80 to $2.30 \mathrm{mg} / \mathrm{dL}$ according to Kaneko et al. (2008), which means that, associated with the fact that serum levels of magnesium reflect dietary intake, and although statistically different, the differences found in the present study do not present biological significance. Cozzi et al. (2011) reported that there was no influence of number of lactations on magnesium levels in the peripartum period, which disagrees with the findings of the present report.

Chloride concentrations varied between groups and moments and increased in M0 when compared to prepartum sampling moments in both $\mathrm{P}$ and $\mathrm{M}$ groups (Table 5). Although this difference was statistically significant, values reported here are within physiological limits established for cows that vary between 95 to $110 \mathrm{mMol} / \mathrm{L}$ (Kaneko et al. 2008), which implies that these findings have no biological significance in the animals evaluated in the present study.
Although there was a variation between groups and moments in serum concentrations of sodium and potassium (Table 5), values found for both electrolytes were within reference range for cows described by Kaneko et al. (2008). According to Van Saun (2007), pre and postpartum sodium levels below $139 \mathrm{mMol} / \mathrm{L}$ and prepartum potassium levels higher than $4.7 \mathrm{mMol} / \mathrm{L}$ are associated with increased postpartum disease risk. In the present study, values found for these variables were not within this risk range, and clinically, there was a low incidence of diseases related to the transition period in the animals studied (data not shown).

Serum levels of cholesterol at M-60 were significantly higher in group $\mathrm{M}$, when compared to group $\mathrm{P}$ (Table 5). Between moments, there was a gradual decrease in cholesterol levels from M-60 to M0 in groups $\mathrm{P}(-18.4 \%)$ and $\mathrm{M}(-34.8 \%)$. Alvarenga et al. (2015) also reported a decrease in cholesterol levels around parturition, and attributed this finding to a moderate decrease in food intake as well as an increase in cortisol levels around parturition, which leads to a decrease in cholesterol synthesis. Pogliani et al. (2010) reported that as multiparous cows are more subject to liver steatosis, they present a marked decrease of cholesterol concentration in the peripartum period, which agrees with the findings of the present study.

Serum levels of triglycerides did not differ between groups although, between moments, there was a marked decrease in $\mathrm{M} 0$ when compared to the other moments in groups P (-30.6\%) and M (-39.5\%) (Table 5). This decrease in triglycerides concentrations is explained by an increased hepatic uptake that occurs as a result of negative energy balance, in order to use this compound as a gluconeogenic precursor (Silva 2009, Pogliani et al. 2010), and in the present study, this was evident in both multiparous and primiparous cows as a result of onset of lactation.

\section{CONCLUSIONS}

Based on these findings, it can be concluded that parity number and the time around calving influence proteinogram and serum constituents of high yielding transition dairy cows.

The biochemical evaluation of cows in the transition period may represent an important tool for evaluation of metabolic balance in the time around calving, should parity number be taken into consideration when interpreting these parameters.

Acknowledgements.- To Fundação de Amparo à Pesquisa do Estado de São Paulo (FAPESP), for the financial support and scholarships granted.

Conflict of interest statement.- The authors have no competing interests.

\section{REFERENCES}

Alvarenga E.A., Moreira G.H.F.A., Facury Filho E.J., Leme F.O.P., Coelho S.G., Molina L.R., Lima J.A.M. \& Carvalho A.U. 2015. Avaliação do perfil metabólico de vacas da raça Holandesa durante o período de transição. Pesq. Vet. Bras. 35(3):281-290. <http://dx.doi.org/10.1590/S0100-736X2015000300012>

Barrington G.M. 2013. Paresia da vaca parturiente, p.1053. In: Kahn C.M. \& Line S. (Eds), Manual Merck de Veterinária. 10a ed. Roca, São Paulo.

Birgel Junior E.H., Neves F.S., Salvatore L.C.A., Mirandola R.M.S., Távora J.P.F. \& Birgel E.H. 2003. Avaliação da influência da gestação e do puerpério sobre a função hepática de bovinos da raça Holandesa. Ars Vet. 19:172-178.

Bossaert P., Trevisi E., Opsomer G., Bertoni G., De Vliegher S. \& Leroy J.L. 2012. The association between indicators of inflammation and liver variables during the transition period in high-yielding dairy cows: an 
observational study. Vet. J. 192(2):222-225. <http://dx.doi.org/10.1016/j. tvjl.2011.06.004><PMid:21742524>

Cozzi G., Ravarotto L., Gottardo F., Stefani A.L., Contiero B., Moro L., Brscic M. \& Dalvit P. 2011. Short communication: reference values for blood parameters in Holstein dairy cows, effects of parity, stage of lactation, and season of production. J. Dairy Sci. 94(8):3895-3901. <http://dx.doi. org/10.3168/jds.2010-3687><PMid:21787926>

Eckersall P.D. 2008. Proteins, proteomics, and dysproteinemias, p.117-155. In: Kaneko J.J., Harvey J.W. \& Bruss M.L. (Eds), Clinical Biochemistry of Domestic Animals. 6th ed. Academic Press, San Diego. <http://dx.doi. org/10.1016/B978-0-12-370491-7.00005-2>.

Kaneko J.J., Harvey J.W. \& Bruss M.L. 2008. Clinical Biochemistry of Domestic Animals. 6th ed. Academic Press, San Diego. 916p.

Laemmli U.K. 1970. Cleavage of structural proteins during the assembly of the head bacteriophage T4. Nature 227(5259):680-685. <http://dx.doi. org/10.1038/227680a0 > <PMid:5432063>

Lager K. \& Jordan E. 2012. The metabolic profile for the modern transition dairy cow. The Mid-South Ruminant Nutrition Conference, Grapevine, Texas, p.9-16.

Larson B.L. \& Touchberry R.W. 1959. Blood serum protein level as a function of age. J. Anim. Sci. 18(3):983-990. <http://dx.doi.org/10.2527/ jas1959.183983x>
Pogliani F.C., Azedo M.R., Souza R.M., Raimondo R.F.S. \& Birgel Junior E.H. 2010. Influência da gestação e do puerpério no lipidograma de bovinos da raça Holandesa. Arq. Bras. Med. Vet. Zootec. 62(2):273-280. <http:// dx.doi.org/10.1590/S0102-09352010000200005>

Rocha T.G., Nociti R.P., Sampaio A.A.M. \& Fagliari J.J. 2012. Passive immunity transfer and serum constituents of crossbred calves. Pesq. Vet. Bras. 32(6):515-522. <http://dx.doi.org/10.1590/S0100-736X2012000600008>

Schneider A., Corrêa M.N. \& Butler W.R. 2013. Short communication: acute phase proteins in Holstein cows diagnosed with uterine infection. Res. Vet. Sci. 95(1):269-271. <http://dx.doi.org/10.1016/j.rvsc.2013.02.010> $<$ PMid:23540606>

Silva P.R.L. 2009. Perfil sanguíneo de fêmeas bovinas em gestação e no periparto e avaliação da transferência de imunidade passiva aos descendentes. Master's Dissertation, Faculdade de Ciências Agrárias e Veterinárias, Universidade Estadual Paulista, Jaboticabal, SP. 87p.

Van Saun R.J. 2004. Metabolic profiling and health risk in transition cows. 37th Annual American Association of Bovine Practitioners Convention, Fort Worth, Texas, p.212-213.

Van Saun R.J. 2007. Metabolic profiling of transition cows: can we predict impending problems? Danske Kvægfagdyrlægers Årsmøde [Danish Bovine Practitioners Seminar], Middelfart, Denmark, p.1-8. 